\title{
Protective effects of Artemisia campestris upon fenthion-induced nephrotoxicity in adult rats and their progeny
}

\author{
Mediha Sefi ${ }^{1}$, Afef Troudi ${ }^{1^{*}}$, Fatma Ben Hamida ${ }^{1^{*}}$, Nejla Soudani ${ }^{1}$, Tahia Boudawara ${ }^{2}$ \\ and Najiba Zeghal ${ }^{1}$ \\ ${ }^{1}$ Animal Physiology Laboratory, UR/08-73, Department of Life Sciences, University of Sfax, Sciences Faculty of Sfax, Tunisia \\ ${ }^{2}$ Histopathology Laboratory, University of Sfax, CHU Habib Bourguiba, Tunisia
}

\begin{abstract}
The purpose of this study was to assess the possible protective effects of Artemisia campestris against fenthion-induced nephrotoxicity in adult rats and their progeny. Fenthion was administered orally at a dose of $551 \mathrm{ppm}$, which represented $1 / 4$ of $\mathrm{LD}_{50}$, for 21 consecutive days to pregnant and lactating rats. Oxidative stress was monitored in the kidney by measuring malondialdehyde (MDA), GSH levels, catalase (CAT), superoxide dismutase (SOD) and glutathione peroxidase activities (GPx). Fenthion caused a significant induction of oxidative damage in kidney as evidenced by increased MDA levels from $5.32 \pm 0.47 \mathrm{nmol} / 100 \mathrm{mg}$ tissue to $11.72 \pm 0.83 \mathrm{nmol} / 100 \mathrm{mg}$ tissue for pups and from $5.18 \pm 0.45 \mathrm{nmol} / 100 \mathrm{mg}$ tissue to $10.84 \pm 1.67 \mathrm{nmol} / 100 \mathrm{mg}$ tissue for dams $(p<0.001)$. A significant increase $(p<0.001)$ in the activities of SOD, CAT and GPx was observed. Co-administration of Artemisia $c$. at a dose of $5 \%(\mathrm{w} / \mathrm{w})$ in the diet of fenthion-treated rats showed a significant reno-protection against fenthion-induced cytotoxic effects. It could be concluded that Artemisia $c$. is promising as a protective agent against nephrotoxicity during the exposure to fenthion.
\end{abstract}

Key words: Adult and suckling rats - Antioxidant activity - Artemisia campestris - Fenthion toxicity - Kidney

\section{Introduction}

Plants have been widely used as food and therapeutical agents in different cultures. Among them, Artemisia campestris L., locally known as T'gouft, is a perennial scarcely aromatic herb of the Asteraceae family that grows spontaneously in the south and the center of Tunisia. Its leaves are widely used in traditional medicine as decoction for their antivenin, anti-inflammatory, antirheumatic and antimicrobial properties (Le Floch 1983). The phytochemical screening of this species revealed the presence of tannins, polyphenols, flavonoids, saponosides, essential oil and minerals (Akrout 2005; Saoudi et al. 2010; Sefi et al. 2010). These bioactive compounds have different biological

\footnotetext{
* These authors contributed equally to this work. Correspondence to: Najiba Zeghal, Animal Physiology Laboratory, UR/08-73, Sciences Faculty of Sfax, BP 1171, 3000 Sfax, University of Sfax, Tunisia

E-mail: najiba.zeghal@tunet.tn naj_zgh@yahoo.fr
}

activities such as antioxidant, antibacterial, hepatoprotective and antivenin properties (Aniya et al. 2000; Djeridane et al. 2006; Memmi et al. 2007). Artemisia c. was reported to be a potent free radical scavenger of 1,1-diphenyl-2picrylhydrazyl (DPPH), hydroxyl and superoxide anion radicals (Aniya et al. 2000). Recently, Akrout et al. (2011) have found that the essential oils, ethanol-water and infusion extracts from Artemisia c. can inhibit the human adenocarcinoma cell growth.

The current study was designed to determine the possible protective effects of Artemisia $c$. supplemented to the diet against kidney biochemical disorders and oxidative damages induced in adult rats and their progeny by a daily ingestion of fenthion for three weeks.

Fenthion is an organophosphorus pesticide (OP) widely used as a broad spectrum insecticide on various crops. This compound is developed as a safe pesticide because it is not easily converted to the possibly highly toxic oxon derivative (fenthion oxon) mammalian species. However, it is extensively marketed in many developing countries, causing death due to acute poisoning (Eddleston and Phillips 2004; 
Eddleston et al. 2007). Repeated exposure to low levels of fenthion can be associated with professional activities through dermal and inhalation route, involving agricultural workers, veterinary personnel, gardeners and florists (Bouvier et al. 2006; Edwards et al. 2008). Moroever, general populations can be exposed to fenthion when they consume vegetables, fruits and fish containing residues of this OP (Kitamura et al. 2003). To our knowledge, there are no reports about the effects of this insecticide on the kidney function of adult rats and their suckling pups.

Despite the folk medicine use, there is no available information in the literature about the protective effects of Artemisia c. leaves against OP. Although we have recently demonstrated that the leaf extracts of Artemisia $c$. contain bioactive compounds such as polyphenols which improve pancreatic $ß$-cells in alloxan-induced diabetic rats (Sefi et al. 2010), the mitigating effects of Artemisia c. against free radicals generation (malondialdehyde), antioxidant enzyme activities in fenthion -induced nephrotoxicity have never been examined. Reports describing fenthion-induced toxicity during life stages after weaning have been carried out on humans (Eddleston et al. 2005), rabbits (Emteres et al. 1986) and rats (Kerem et al. 2007). Yet, studies on the effects of fenthion intoxication during the early developing stages of life appeared to be lacking. Therefore, the aim of this study was to determine the effects of fenthion exposure on the kidney of adult rats and their progeny and to assess whether these effects could be improved by co-treatment with Artemisia $c$.

\section{Material and Methods}

\section{Chemicals}

The chemical name of fenthion is [O,O-dimethyl O-[3-methyl-4-(methylthio)phenyl]phosphorothioate]. According to our previous paper (Sefi et al. 2011), its commercialization is sold as "Lebaycid 50 EC" (Bayer Crop Science, Ariana-Charguia, 2035, Tunis-Carthage) containing 50\% of fenthion, an active ingredient of the product.

All other chemical products used in this study were purchased from Sigma Chemical Co. (St. Louis, France).

\section{Artemisia campestris source}

The aerial parts of the plant were collected in August 2008 at Kssour-Essef in Mahdia city, Tunisia. Artemisia campestris was botanically identified according to the flora of Tunisia by Prof. Abdelhamid Nabli (Faculty of Sciences, University of Tunis El Manar). A voucher specimen (Cuenod et al. 1954) was deposited in the Faculty of Pharmacy (Monastir, Tunisia).

\section{Artemisia campestris leaf extracts preparation}

Air-dried leaves of the plant were divided into three parts weighing $25 \mathrm{~g}$ each. Then they were finely powdered and extracted by maceration with $(3 \times 250 \mathrm{ml})$ of water at ambient temperature for $3 \mathrm{~h}$ with continuous stirring. The process was repeated twice. The aqueous extracts were filtrated with $\mathrm{N}^{\circ} 1$ Whatmann Millipore filter paper $(0.45 \mu \mathrm{m}$ Ref HAWP04700, Bedford, MA, USA) and concentrated to dryness with a rotary evaporator at $50 \pm 1^{\circ} \mathrm{C}$ to give solid residues. The yield was calculated to be $19.36 \pm 0.02 \%$. The dried extracts were kept in the dark at $4^{\circ} \mathrm{C}$ prior analysis.

\section{In vitro antioxidant activities in Artemisia leaf extracts}

The dried leaf extracts of Artemisia campestris were re-dissolved in water at a concentration of $4 \mathrm{mg} / \mathrm{ml}$ for the determination of its antioxidant compounds.

\section{Antioxidant activity based on the DPPH assay}

The effect of plant extracts on $\mathrm{DPPH}$ radical $\left(\mathrm{DPPH}^{\bullet}\right)$ was estimated using the method of Liyana-Pathiranan and Shahidi (2005) with slight modifications. Samples of plant extract $(4.0 \mathrm{mg} / \mathrm{ml})$ and of ascorbic acid used as standard were diluted in methanol to final concentrations of 2, 3.5, $7.5,25$ and $62.5 \mu \mathrm{g} / \mathrm{ml}$. Then $1 \mathrm{ml}$ of DPPH methanol solution $(0.135 \mathrm{mM})$ was added to $1 \mathrm{ml}$ of sample solution of different concentrations and allowed to react in a dark place at room temperature. After $30 \mathrm{~min}$, the absorbance values were measured at $517 \mathrm{~nm}$ and converted into the percentage antioxidant activity using the following equation: scavenging capacity $\%=\left[\left(\mathrm{Abs}_{\text {control }}-\mathrm{Abs}_{\text {sample }}\right) / \mathrm{Abs}_{\text {control }}\right] \times 100$, where $\mathrm{Abs}_{\text {control }}$ is the absorbance of the $\mathrm{DPPH}^{\circ}+$ methanol, $\mathrm{Abs}_{\text {sample }}$ is the absorbance of $\mathrm{DPPH}^{\bullet}+$ sample extract/ standard.

The antioxidant activity of Artemisia c. leaf extract or ascorbic acid used as standard was expressed as $\mathrm{IC}_{50}$, defined as the concentration of the test extract or ascorbic acid required to cause a $50 \%$ decrease in initial $\mathrm{DPPH}$ concentration.

\section{Antioxidant activity based on the reducing power assay}

The reducing power of the prepared extracts was determined according to the methods of Oyaizu (1986) and Yen and Chen (1995) with slight modifications. Briefly, $100 \mu \mathrm{l}$ of each extract $(0.062-4.0 \mathrm{mg} / \mathrm{ml})$ or ascorbic acid, used as standard reference, dissolved in methanol were added to $250 \mu \mathrm{l}$ of a $0.2 \mathrm{M}$ phosphate buffer ( $\mathrm{pH}$ 6.6) and $250 \mu \mathrm{l}$ of a $1 \%(\mathrm{w} / \mathrm{v})$ solution of potassium ferricyanide $\left[\mathrm{K}_{3} \mathrm{Fe}(\mathrm{CN})_{6}\right]$. The mixture was incubated in a water bath at $50^{\circ} \mathrm{C}$ for $20 \mathrm{~min}$. Then, $250 \mu \mathrm{l}$ of a $10 \%(\mathrm{w} / \mathrm{v})$ trichloroacetic acid solution (TCA) were 
added and the mixture was centrifuged at $1750 \times g$ for $10 \mathrm{~min}$. A $250 \mu$ aliquot of the upper layer was combined with $250 \mu \mathrm{l}$ of distilled water and $500 \mu \mathrm{l}$ of a $0.1 \%(\mathrm{w} / \mathrm{v})$ solution of ferric chloride $\left(\mathrm{Fe} \mathrm{Cl}_{3}\right)$. Absorbance of each reaction mixture was read spectrophotometrically at $700 \mathrm{~nm}$. Its increase indicated a high reducing power. Mean values from three independent samples were calculated for each extract or standard.

\section{Animals}

Experiments were performed on male and female Wistar rats weighing $180 \mathrm{~g}$ purchased from SIPHAT (Tunisia). Food (SICO, Tunisia) and water were available ad libitum. After a 1-week adaptation period in a room with controlled temperature $\left(22 \pm 3^{\circ} \mathrm{C}\right)$ and lighting (12-h light/12-h dark), female rats were mated with males. A sperm-positive vaginal smear was taken to indicate the first day of pregnancy.

The general guidelines for the use and care of living animals in scientific investigations were followed (Council of European Communities, 1986). The handling of the animals was approved by the Tunisian Ethical Committee for the Care and Use of laboratory animals.

\section{Experimental procedure}

Twenty-four pregnant rats of Wistar strain were randomly divided into four groups of six each. The first group (C) served as negative control which received distilled drinking water. The second group (FEN) received via drinking water only fenthion (551 ppm equivalent to $61 \mathrm{mg} / \mathrm{kg} \mathrm{bw}$ ). This dose which represented the $1 / 4$ of $\mathrm{LD}_{50}$ was opted because it generated a moderate oxidative stress as reported in our previous paper (Sefi et al. 2011). The two groups received standard diet. Animals of the third group (FEN+Ac) received both $551 \mathrm{ppm}$ of fenthion and were fed with diet supplemented with fine leaf powder of Artemisia c. at 5\% (w/w) levels according to previous studies (Uz et al. 2009). The fourth group (Ac) served as positive control and received only experimental diet (5\% Artemisia c). All treatments were started from the $14^{\text {th }}$ day of pregnancy until day 14 after delivery. Pregnant female rats were allowed to deliver spontaneously three weeks after coitus. No delay was observed in the delivery of the treated groups. Within $24 \mathrm{~h}$ after birth, the litters were reduced to 8 pups for each mother (four males and four females if possible) to ensure standardized nutrition and maternal care (Fishbeck and Rasmussen 1987).

Urinary samples, collected into bottles within 24-h cycles, were obtained from each animal housed in a specially designed metabolic cage where faecal contamination was avoided. The urinary volume of 14-day-old rats was calculated by taking away the 24-h urine volume of mothers kept with their pups and of those kept alone in metabolic cages. The volume of each sample was recorded and centrifuged at $3000 \times g$ for $5 \mathrm{~min}$.

On day 14 after delivery, all pups $(n=192)$ and dams $(n=24)$ were sacrificed after anesthesia by intra-abdominal injection with chloral hydrate. Blood was collected in heparined tubes from the brachial artery of pups and via the aortic puncture of adult rats. Plasma samples were drawn from blood after centrifugation at $2200 \times g$. Both plasma and urine samples were kept at $-20^{\circ} \mathrm{C}$ until analysis.

Kidneys (right or left), removed from adipose tissue and adrenal glands, were taken from mothers and their offspring, washed with saline solution and weighed. Some kidney samples, taken from mothers and pups, were homogenized (10\%, $\mathrm{w} / \mathrm{v})$ in phosphate buffer $(0.1 \mathrm{M}, \mathrm{pH}$ 7.4) and centrifuged at $10.000 \times g$ for $10 \mathrm{~min}$. The resulting and clear supernatants were used for biochemical assays. Other kidneys were used for histological studies.

\section{Biochemical assays}

\section{Lipid peroxidation}

The concentration of malondialdehyde (MDA) in tissues, an index of lipid peroxidation, was determined spectrophotometrically according to Draper and Hadley (1990). An aliquot of $0.5 \mathrm{ml}$ of kidney extract supernatant was mixed with $1 \mathrm{ml}$ of trichloroacetic acid solution and centrifuged at $4000 \times g$ for $10 \mathrm{~min}$. One milliliter of a solution containing $0.67 \%$ thiobarbituric acid (TBA) and $0.5 \mathrm{ml}$ of supernatant were incubated for $15 \mathrm{~min}$ at $90^{\circ} \mathrm{C}$ and cooled. Absorbance of TBA-MDA complex was determined at $532 \mathrm{~nm}$ using a spectrophotometer. Lipid peroxidation was expressed as nmoles of thiobarbituric acid reactive substances (TBARS), using 1,1,3,3-tetra-ethoxypropane as standard.

\section{Kidney GSH levels}

The renal GSH contents were determined by Ellman's method (Ellman 1959), modified by Jollow et al. (1974) based on the development of a yellow color when 5,5-dithiobis-2 nitro benzoic acid (DTNB) was added to compounds containing sulfhydryl groups. Briefly, $3 \mathrm{ml}$ of sulfosalicylic acid (4\%) was added to $500 \mu$ of kidney homogenate in phosphate buffer for deproteinisation. The mixture was centrifuged at 2500 $\times g$ for $15 \mathrm{~min}$. Then Ellman's reagent was added to $500 \mu \mathrm{l}$ of supernatant. The absorbance was measured at $412 \mathrm{~nm}$ after $10 \mathrm{~min}$. Total GSH content was expressed as $\mathrm{mg} / \mathrm{g}$ of tissue.

\section{Determination of antioxidant enzyme activities}

- The catalase (CAT) activity was assayed by the method of Aebi (1984). Enzymatic reaction was initiated by add- 
ing an aliquot of $20 \mu \mathrm{l}$ of the homogenized tissue and the substrate $\left(\mathrm{H}_{2} \mathrm{O}_{2}\right)$ to a concentration of $0.5 \mathrm{M}$ in a medium containing $100 \mathrm{mM}$ phosphate buffer, $\mathrm{pH}$ 7.4. Changes in absorbance were recorded at $240 \mathrm{~nm}$. The enzyme activity was expressed as $\mu \mathrm{mol} \mathrm{H}_{2} \mathrm{O}_{2}$ consumed $/ \mathrm{min} / \mathrm{mg}$ protein.

- Superoxide dismutase (SOD) activity was estimated according to Beauchamp and Fridovich (1971). The reaction mixture contained $50 \mu \mathrm{l}$ of kidney homogenates in $0.1 \mathrm{M}$ of potassium phosphate buffer ( $\mathrm{pH}$ 7.4), $0.1 \mathrm{mM}$ EDTA, $13 \mathrm{mM}$ L-methionine, $2 \mathrm{mM}$ riboflavin and $75 \mathrm{mM}$ nitro blue tetrazolium (NBT). The developed blue color in the reaction was measured at $560 \mathrm{~nm}$. Units of SOD activity were expressed as the amount of enzyme required to inhibit the reduction of NBT by $50 \%$ and the activity was expressed as units per mg of protein.

- Glutathione peroxidase (GPx) activity was measured according to Flohe and Gunzler (1984). GPx catalyzes the oxidation of reduced glutathione by cumene hydroperoxide. In the presence of reduced glutathione reductase and nicotinamide adenine dinucleotide phosphate reduced form (NADPH), the oxidized reduced glutathione is immediately converted to the reduced form with a concomitant oxidation of NADPH-NADP ${ }^{+}$. The decrease in absorbance at $340 \mathrm{~nm}$ was measured. The enzyme activity was expressed as nmoles of GSH oxidized/min/mg protein.

\section{Protein quantification}

Protein content was measured according to Lowry et al. (1951) using bovine serum albumin (BSA) as standard.

Table 1. DPPH free-radical scavenging activity of leaf extract from Artemisia campestris and ascorbic acid (antioxidant reference)

\begin{tabular}{lccc}
\hline Samples & $\begin{array}{c}\text { Concentration } \\
(\mu \mathrm{g} / \mathrm{ml})\end{array}$ & $\begin{array}{c}\text { Inhibition of } \\
\mathrm{DPPH}^{\bullet} \\
(\%)^{\mathrm{a}}\end{array}$ & $\begin{array}{c}\mathrm{IC}_{50} \\
(\mu \mathrm{g} / \mathrm{ml})\end{array}$ \\
\hline Artemisia c. & 2 & 0 & $>62.5$ \\
leaf extracts & 3.5 & 0 & \\
& 7.5 & 0 & \\
Ascorbic acid $^{\mathrm{b}}$ & 25 & 0 & \\
\cline { 2 - 4 } & 62.5 & $28.83 \pm 0.9$ & \\
& 2 & $37.86 \pm 2.4$ & $2<\mathrm{IC}_{50}<3.5$ \\
& 3.5 & $69.38 \pm 1.5$ & \\
& 7.5 & $92.57 \pm 1.7$ & \\
\hline
\end{tabular}

Values represent the means of three replicates \pm SE. ${ }^{a}$ Inhibition of absorbance at $517 \mathrm{~nm}$ relative to that of standard DPPH solution; ${ }^{\mathrm{b}}$ positive control of antioxidant effect.

\section{Assessment of renal function}

The levels of urea and creatinine in plasma and urine were estimated spectrophotometrically using commercial diagnostic kits, respectively (ref 20151, 20091), purchased from Biomagreb (Ariana, Tunisia). Creatinine clearance, an index of glomerular filtration rate, was calculated by UV/P equation (Charrel 1991), where $U$ is the urinary creatinine level, $\mathrm{V}$ the volume of urine sample collected within $24 \mathrm{~h}$ and $\mathrm{P}$ the plasma creatinine concentration.

\section{Histopathological examination}

Some kidney samples were removed from pups and mothers, immediately fixed in $10 \%$ of formalin solution for $48 \mathrm{~h}$ and processed in a series of graded ethanol solutions. They were then embedded in paraffin, serially sectioned at $5 \mu \mathrm{m}$ and stained with hematoxylin-eosin for light microscopy examination (Gabe 1968).

\section{Statistical analysis}

The data were analyzed using the statistical package program Stat view 5 Software for Windows (SAS Institute, Berkley, CA, USA). Statistical analysis was performed using oneway analysis of variance (ANOVA) followed by Fisher's protected least significant difference (PLSD) test as a post hoc test for comparison between groups: (FEN , FEN+Ac, Ac) vs. $\mathrm{C}$ and between groups: $(\mathrm{FEN}+\mathrm{Ac})$ vs. FEN. All values were expressed as means \pm S.E. Differences were considered significant if $p<0.05$.

\section{Results}

\section{Antioxidant activities}

\section{Radical-scavenging activity on $\mathrm{DPPH}$}

The scavenging capacity of Artemisia campestris leaf extract on DPPH inhibition is shown in Table 1. The results indicated that Artemisia c. extract, at a concentration of $62.5 \mu \mathrm{g} / \mathrm{ml}$, inhibited the formation of $\mathrm{DPPH}^{\bullet}$ by $28.83 \%$. The $\mathrm{DPPH}^{\bullet}$ scavenging activity was enhanced with the increase of concentration. The antioxidant activity of ascorbic acid used as standard reference was found stronger than Artemisia c. leaf extracts. The data obtained in this study revealed that only $62.5 \mu \mathrm{g} / \mathrm{ml}$ of the tested extract had a significant free radical scavenger which reacted with $\mathrm{DPPH}^{\bullet}$ owing to its electron-donating ability. In fact $\mathrm{IC}_{50}$, the concentration of the tested extracts required to cause a $50 \%$ decrease in initial DPPH concentration, was obtained when the concentration of Artemisia c. leaf extract was higher than $62.5 \mu \mathrm{g} / \mathrm{ml}$, 
while $\mathrm{IC}_{50}$ for ascorbic acid sample, used as standard, was estimated between 2 and $3.5 \mu \mathrm{g} / \mathrm{ml}$.

\section{Reducing antioxidant power}

The reducing antioxidant power of Artemisia $c$. leaf extract is shown in Fig. 1. The result suggested that the extract had a reducing power, which was enhanced when concentrations increased. Ascorbic acid, used as standard reference, showed higher reducing power than Artemisia c. leaf extract.

\section{Food and water consumption}

Daily food intake by treated rats (FEN, FEN+Ac and Ac) was similar to that of controls rats. In FEN group, a marked increase in the daily water intake was observed $(+34 \%)$ when compared to controls (Table 2). The administration of Artemisia c. leaf powder in the diet of fenthion-treated rats normalised water intake when compared to FEN group. Artemisia c. leaf powder, incorporated in the diet of control rats, had no effects on daily water intake.

\section{Lipid peroxidation of the kidney}

Compared to controls, treatment with fenthion increased MDA levels by $120 \%$ in pups and by $109 \%$ in their mothers. Supplementation of Artemisia $c$. leaf powder in the diet of fenthiontreated rats resulted in a decrease of kidney MDA levels both in dams and suckling pups compared to those of fenthion-treated rats. This effect was more pronounced in dams. Artemisia $c$. leaf powder administered in the diet of control rats produced no changes in MDA levels in kidney (Table 3).

\section{Enzymatic antioxidant status in kidney}

The exposure of adult rats to fenthion for 21 days caused a significant increase in CAT, SOD and GPx activities by 97 , 17 and $165 \%$ in pups and by 67,39 , and $103 \%$ in kidney of their mothers, respectively, compared to those of controls

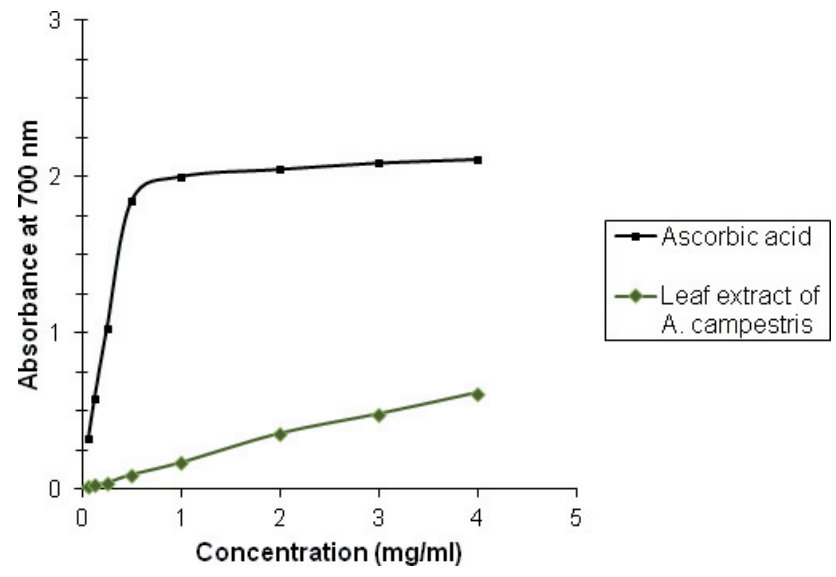

Figure 1. Reducing power activities of Artemisia campestris leaf aqueous extract in comparison with ascorbic acid, used as standard. Values represent the means of three replicates $\pm \mathrm{SE}$.

(Table 3). Co-treatment with Artemisia c. leaf powder significantly improved CAT, SOD and GPx activities in pups and their mothers when compared to FEN group. Artemisia $c$. leaf powder, incorporated in the diet of control rats, had no effects on antioxidant enzymes activities.

\section{Kidney glutathione (GSH) content}

After fenthion treatment, no significant changes were observed in kidney GSH content both in dams and pups (Table 3). The administration of Artemisia c. leaf powder in the diet of fenthion-treated rats and control rats didn't modify GSH values.

\section{Renal biomarkers evaluation}

Results showed that the creatinine and urea levels of FEN group were respectively higher in the plasma of pups $(+31 \%,+49 \%)$ and of their mothers $(+29 \%,+22 \%)$ and lower in the urine of pups $(-27 \%,-32 \%)$ and of their mothers $(-35 \%,-48 \%)$ than those of the corresponding controls (Table 4 ). So, a reduction

Table 2. Daily water and food consumption by adult rats of different groups: control group, treated with fenthion, treated with Artemisia c. leaf powder along with fenthion, and treated with Artemisia $c$. leaf powder from the $14^{\text {th }}$ day of pregnancy until day 14 after delivery

\begin{tabular}{lcccc}
\hline Groups & $\begin{array}{c}\text { Water consumption } \\
(\mathrm{ml} / \text { day/dam })\end{array}$ & $\begin{array}{c}\text { Food consumption } \\
(\mathrm{g} / \text { day/dam })\end{array}$ & $\begin{array}{c}\text { Ingested fenthion quantities } \\
(\mathrm{mg} / \text { day/dam })\end{array}$ & $\begin{array}{c}\text { Ingested Artemisia } \text { c. quantities } \\
(\mathrm{g} / \mathrm{day} / \mathrm{dam})\end{array}$ \\
\hline $\mathrm{C}$ & $24.10 \pm 0.46$ & $18.82 \pm 1.60$ & - & - \\
FEN & $32.35 \pm 0.53^{* * *}$ & $17.41 \pm 1.10$ & $18.21 \pm 1.63$ & - \\
FEN+Ac & $29.24 \pm 0.44^{* *}$ & $17.83 \pm 0.36$ & $15.92 \pm 0.30^{+}$ & $0.89 \pm 0.01$ \\
Ac & $24.55 \pm 0.27$ & $18.86 \pm 0.23$ & - & $0.94 \pm 0.01$ \\
\hline
\end{tabular}

C, control group; FEN, group treated with $551 \mathrm{ppm}$ fenthion; FEN+Ac, group treated with Artemisia c. leaf powder along with fenthion; Ac, group treated with Artemisia c. leaf powder. Values are means \pm SE for six rats in each group. For all treated groups: ${ }^{* *} p<0.01$, $^{* *} p<$ 0.001 vs. C group. For FEN+AC group: ${ }^{+} p<0.05$ vs. FEN group. 
Table 3. Malondialdehyde (MDA) content, antioxidant enzymes activities (CAT, SOD and GPx) and reduced glutathione (GSH) levels in kidney of suckling and adult rats of different groups: control group, group treated with fenthion, treated with Artemisia c. leaf powder along with fenthion, and treated with Artemisia $c$. leaf powder from the $14^{\text {th }}$ day of pregnancy until day 14 after delivery

\begin{tabular}{|c|c|c|c|c|c|c|}
\hline Groups & & $\begin{array}{c}\text { MDA } \\
\text { (nmoles } / 100 \mathrm{mg} \\
\text { tissue) }\end{array}$ & $\begin{array}{c}\text { CAT } \\
\begin{array}{c}\mu \text { moles } \mathrm{H}_{2} \mathrm{O}_{2} \text { degraded} / \\
\mathrm{min} / \mathrm{mg} \text { protein })\end{array}\end{array}$ & $\begin{array}{c}\text { SOD } \\
\text { (U/mg protein) }\end{array}$ & 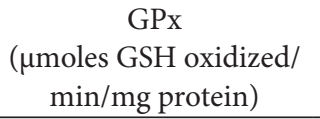 & $\begin{array}{c}\text { GSH } \\
(\mu \mathrm{g} / \mathrm{g} \text { tissue })\end{array}$ \\
\hline \multirow{2}{*}{ C } & Offspring & $5.32 \pm 0.50$ & $7.44 \pm 1$ & $86.86 \pm 7.13$ & $0.09 \pm 0.02$ & $91.35 \pm 5.85$ \\
\hline & Mothers & $5.18 \pm 0.45$ & $11.59 \pm 0.78$ & $30.18 \pm 3.80$ & $0.07 \pm 0.01$ & $84.76 \pm 1.01$ \\
\hline \multirow{2}{*}{ FEN } & Offspring & $11.72 \pm 0.83^{* \neq x}$ & $14.69 \pm 0.83^{* \star x}$ & $101.81 \pm 5.3^{x+x}$ & $0.24 \pm 0.03^{* * *}$ & $91.96 \pm 4.41$ \\
\hline & Mothers & $10.84 \pm 1.7^{* * *}$ & $19.40 \pm 1.4^{* * *}$ & $42.05 \pm 1.85^{\star * *}$ & $0.16 \pm 0.01^{* * *}$ & $84.66 \pm 1.33$ \\
\hline \multirow{2}{*}{$\mathrm{FEN}+\mathrm{Ac}$} & Offspring & $9.69 \pm 1^{* * *++}$ & $10.52 \pm 1.32^{* *+++}$ & $90.29 \pm 1.95^{+++}$ & $0.15 \pm 0.03^{* x}+++$ & $91.69 \pm 2.21$ \\
\hline & Mothers & $6.22 \pm 0.33^{*+++}$ & $13.01 \pm 1.03^{*+++}$ & $32.03 \pm 2.24^{+++}$ & $0.11 \pm 0.02^{* *}++$ & $84.74 \pm 1.41$ \\
\hline \multirow{2}{*}{ Ac } & Offspring & $5.53 \pm 0.40$ & $7.11 \pm 0.60$ & $85.92 \pm 2.43$ & $0.087 \pm 0.02$ & $91.25 \pm 3.93$ \\
\hline & Mothers & $5.56 \pm 0.33$ & $11.73 \pm 0.57$ & $30.41 \pm 1$ & $0.07 \pm 0.01$ & $84.52 \pm 0.95$ \\
\hline
\end{tabular}

C, control group; FEN, group treated with 551 ppm fenthion; FEN+Ac, group treated with Artemisia c. leaf powder along with fenthion; Ac, group treated with Artemisia $c$. leaf powder. The number of determinations is indicated in parenthesis. $n=8$ for offspring; $n=6$ for mothers. For all treated groups: ${ }^{\star} p<0.05,{ }^{* *} p<0.01,{ }^{* *} p<0.001 v$ s. C group. For FEN+AC group: ${ }^{++} p<0.01,{ }^{+++} p<0.001$ vs. FEN group.

in creatinine clearance, an indicator of glomerular dysfunction, was found in pups (-72\%) and their mothers (-73\%) (Fig. 2A and $\mathrm{B})$. In addition, the 24 - $\mathrm{h}$ urine volume in fenthion-treated pups and their mothers was lower than in controls (Fig. 3A and B). Co-treatment with Artemisia c. leaf powder improved these parameters. No significant changes were observed between control and Artemisia c.-treated groups.

\section{Histopathological examination}

The histological analysis of kidneys in fenthion-treated dams showed the presence of damaged renal tubules, including necrotic epithelial cells with marked tubular dilatation (Fig. 4B1). Furthermore, there were a narrowed Bowman's space and mononuclear cells infiltration around the glomeruli (Fig. 4B2) and between the tubules (Fig. 4B3). In their pups, a narrowed Bowman's space, a slight tubular dilatation (Fig. 5B1) and granuloma inflammatory disorders were shown (Fig. 5B2). Kidney histological changes were more pronounced in fenthion-treated dams than in their pups. These changes were moderately improved with Artemisia c. treatment in the kidney of dams, showing a normal Bowman's space in the glomeruli (Fig. 4C) and some tubular necrosis in the proximal tubular cells (Fig. 4D). In pups, a slight recovery in renal glomeruli and tubules was observed (Fig. 5C). There were no histological alterations in the kidneys of Artemisia c. leaf powder-treated dams and their pups (Figs. 4E and 5D) when compared to control groups (Figs. 4A and 5A).

\section{Discussion}

The oral administration of fenthion to adult rats caused nephrotoxicity or kidney injury as monitored by the distur-

Table 4. Plasma and urinary levels of creatinine, urea and blood urea nitrogen of suckling and adult rats of different groups: control group, group treated with fenthion, treated with Artemisia c. leaf powder along with fenthion, and treated with Artemisia c. leaf powder from the $14^{\text {th }}$ day of pregnancy until day 14 after delivery

\begin{tabular}{|c|c|c|c|c|c|c|}
\hline \multirow{2}{*}{ Groups } & & \multicolumn{2}{|c|}{ Creatinine $(\mu \mathrm{mol} / \mathrm{l})$} & \multicolumn{2}{|c|}{ Urea $(\mathrm{mmol} / \mathrm{l})$} & \multirow{2}{*}{$\mathrm{BUN}^{\mathrm{a}}$} \\
\hline & & Plasma & Urine & Plasma & Urine & \\
\hline \multirow{2}{*}{ C } & Offspring & $55.25 \pm 5.10$ & $8680.88 \pm 255.7$ & $3.96 \pm 0.33$ & $889.51 \pm 20.1$ & $11.12 \pm 0.93$ \\
\hline & Mothers & $55.65 \pm 5.10$ & $7755.62 \pm 152.8$ & $8.81 \pm 0.41$ & $754.07 \pm 16.8$ & $24.72 \pm 1.2$ \\
\hline \multirow{2}{*}{ FEN } & Offspring & $72.43 \pm 5.08^{* * *}$ & $6294.08 \pm 141.44^{* * *}$ & $5.93 \pm 0.3^{* * *}$ & $598.13 \pm 25.64^{* * *}$ & $16.66 \pm 0.82^{* * *}$ \\
\hline & Mothers & $72.02 \pm 5.10^{* * *}$ & $4973.97 \pm 226.6^{* * *}$ & $10.77 \pm 0.25^{* * *}$ & $387.29 \pm 22.8^{* * *}$ & $30.22 \pm 0.72^{* * *}$ \\
\hline \multirow{2}{*}{$\mathrm{FEN}+\mathrm{Ac}$} & Offspring & $63.11 \pm 3.30^{\star *}++$ & $7956 \pm 196.42^{\star *}+++$ & $5.40 \pm 0.25^{* * *}$ & $730.24 \pm 22.70^{\star *}+++$ & $16.32 \pm 0.80^{* * *}$ \\
\hline & Mothers & $59.84 \pm 5.10^{\star++}$ & $6411.94 \pm 152.8^{\star *}+++$ & $9.80 \pm 0.48^{\star *}+$ & $524.83 \pm 18.73^{\star * *}+++$ & $29.41 \pm 1.6^{* * *}$ \\
\hline \multirow{2}{*}{ Ac } & Offspring & $56.75 \pm 3.30$ & $8601.32 \pm 184.94$ & $3.90 \pm 0.08$ & $881.74 \pm 15.35$ & $11.50 \pm 0.30$ \\
\hline & Mothers & $56.02 \pm 5.10$ & $7673.12 \pm 165.85$ & $8.65 \pm 0.14$ & $752.80 \pm 12.23$ & $24.12 \pm 0.50$ \\
\hline
\end{tabular}

C, control group; FEN, group treated with 551 ppm fenthion; FEN+Ac, group treated with Artemisia c. leaf powder along with fenthion; Ac, group treated with Artemisia $c$. leaf powder. ${ }^{a}$ Blood urea nitrogen was calculated using the formula conversion: BUN (mg/dl) $=[\mathrm{urea}$ $(\mathrm{mg} / \mathrm{dl})] / 2.14$. The number of determinations is: $n=8$ for offspring; $n=6$ for mothers. For all treated groups: ${ }^{\star} p<0.05,{ }^{\star *} p<0.01$, ${ }^{* * *} p<0.001$ vs. C group. For FEN+AC group: ${ }^{+} p<0.05,{ }^{++} p<0.01,{ }^{+++} p<0.001$ vs. FEN group. 
bance in the levels of renal biomarkers like creatinine, urea, creatinine clearance and 24-h urine volume, as well as renal MDA levels, thus causing a drastic alteration in antioxidant defense system. Particularly, the activities of CAT, SOD, and GPx increased by FEN. These biochemical alterations were accompanied by histological changes marked by the damaged renal tubules like necrotic epithelial cells with a marked tubular dilatation, a narrowed Bowman's space and leucocytes infiltration around glomeruli and between tubules in the kidney of dams. In pups, a narrowed Bowman's space, a slight tubular dilatation and granuloma inflammatory disorders were shown. Our results were in accordance with our previous studies which we have found nephrotoxicity after treatment with other compounds such as methimazole, an antithyroid drug (Ben Amara et al. 2011); 2,4 dichlorophenoxyacetic acid, an herbicide (Troudi et al. 2011) and chromium (VI), a heavy metal (Soudani et al. 2010, 2011).

In the current study, we aimed to recognize if a leaf powder of Artemisia c., incorporated in the diet, was sufficient to protect the rats against the toxic effects of fenthion. To our knowledge, this is the first report which investigates the
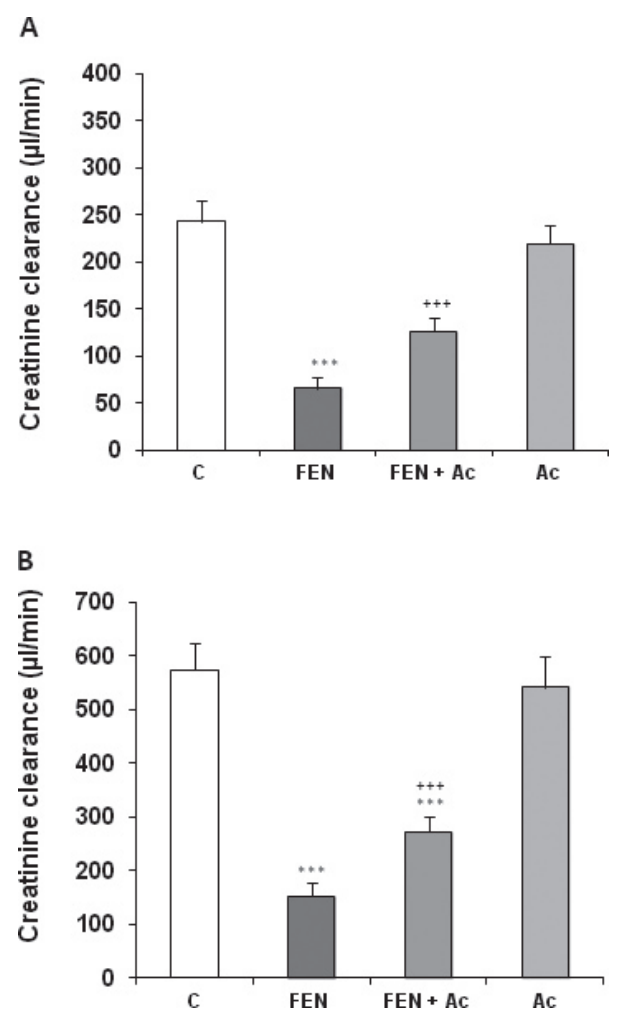

Figure 2. Creatinine clearance of suckling (A) and adult rats (B), controls or treated with fenthion (FEN), fenthion and Artemisia c. (FEN+Ac) or Artemisia c. (Ac) from the 14th day of pregnancy until day 14 after delivery. The number of determinations is: $n=8$ for offspring; $n=6$ for mothers. For all treated groups: ${ }^{* *} p<0.001 v$ s. control group (C). For FEN+AC group: ${ }^{+++} p<0.001$ vs. FEN group.
A

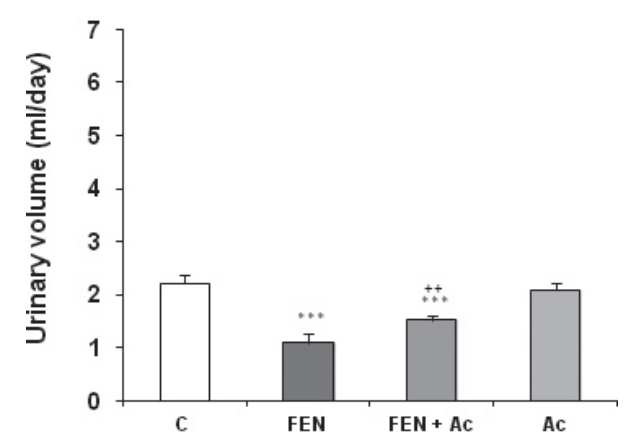

B

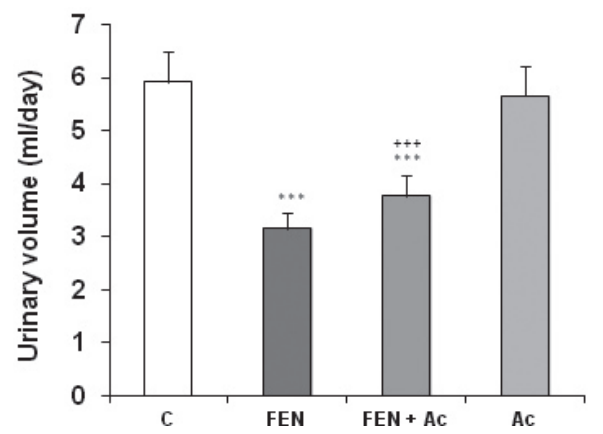

Figure 3. Urinary volume of suckling (A) and adult rats (B), controls or treated with fenthion (FEN), fenthion and Artemisia c. (FEN+Ac) or Artemisia c. (Ac) from the 14th day of pregnancy until day 14 after delivery The number of determinations is: $n=8$ for offspring; $n=6$ for mothers. For all treated groups: ${ }^{* *} p<0.001 v$ s. control group (C). For FEN+AC group: ${ }^{++} p<0.01,{ }^{+++} p<0.001 v s$. FEN group.

protective effects of Artemisia c. on nephrotoxicity induced by fenthion in adult rats and their progeny.

We have determined in our previous study the antioxidant contents of Artemisia c. Total flavonoids were the dominant phenolic compounds of the plant aqueous extract (Sefi et al. 2010). Chemical constituents of Artemisia c., harvested in France and Portugal, were determined. In fact, previous studies on the chemical composition of Artemisia c. ssp. glutinosa have been reported by Hurabielle et al. (1982). Four flavanones (pinostrobin, pinocembrin, sakuranetin and naringenin), one dihydroflavonol (7-methyl aromadendrin) and one flavone (hispidulin) have been isolated and identified by spectroscopic methods.

Similar results were reported by Rauter et al. (1989) concerning the chemical constituents of Artemisia c. ssp maritima. Two new flavanones 5,8,4'-trihydroxyflavanone and 5,6-dihydroxy4'-methoxyflavanone were obtained, for the first time, from a natural source. Three other flavanones, the known natural products, were also isolated from this species: 5,4'-dihydroxy7,3'-dimethoxyflavanone; 7,3'-dimethoxy-3,5,4'-trihydroxyflavanone and 5,4'-dihydroxy-6,7 dimethoxyflavone. 

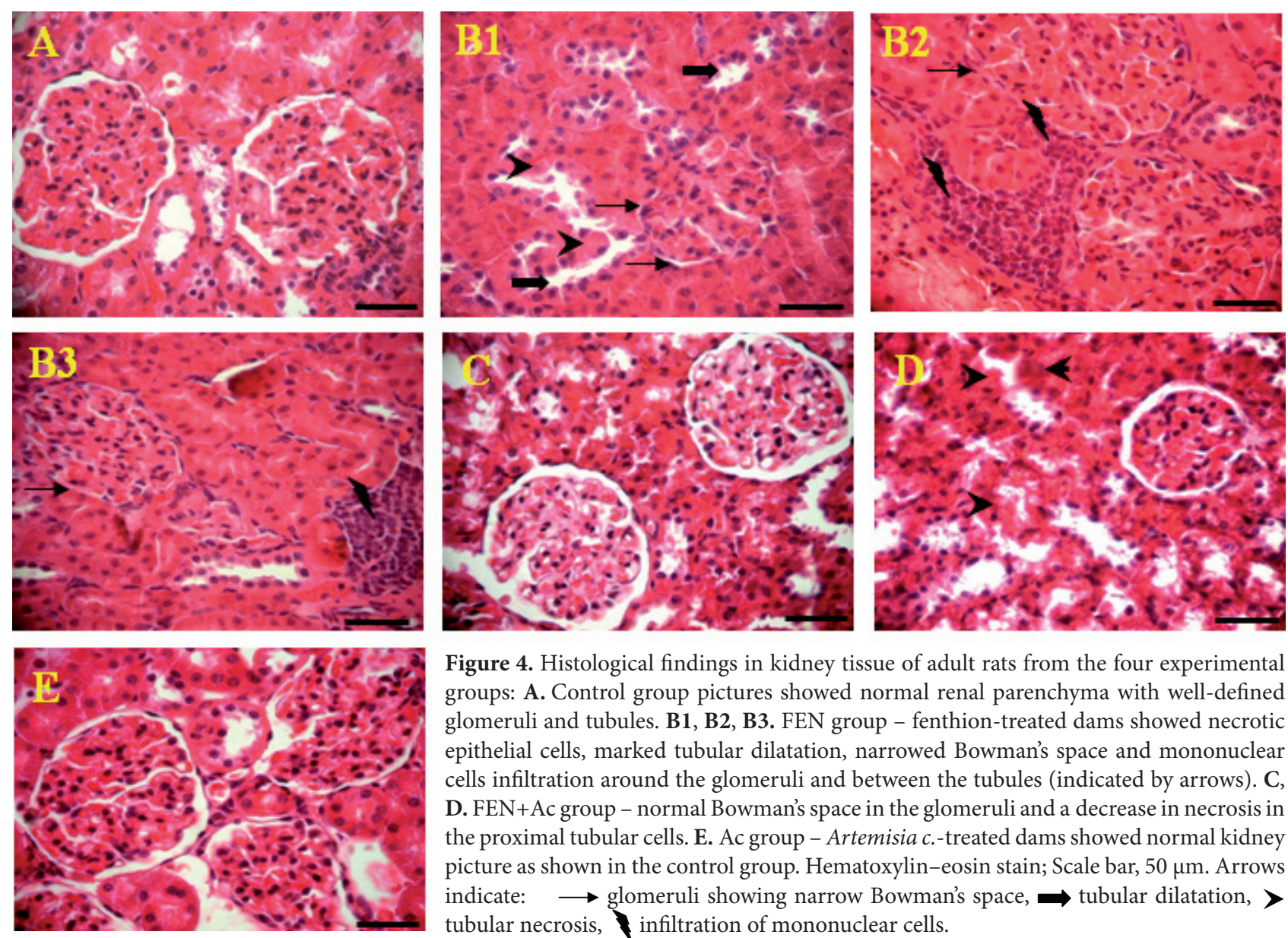

Figure 4. Histological findings in kidney tissue of adult rats from the four experimental groups: A. Control group pictures showed normal renal parenchyma with well-defined glomeruli and tubules. B1, B2, B3. FEN group - fenthion-treated dams showed necrotic epithelial cells, marked tubular dilatation, narrowed Bowman's space and mononuclear cells infiltration around the glomeruli and between the tubules (indicated by arrows). C, D. FEN+Ac group - normal Bowman's space in the glomeruli and a decrease in necrosis in the proximal tubular cells. E. Ac group - Artemisia c.-treated dams showed normal kidney picture as shown in the control group. Hematoxylin-eosin stain; Scale bar, $50 \mu \mathrm{m}$. Arrows indicate: $\longrightarrow$ glomeruli showing narrow Bowman's space, $\rightarrow$ tubular dilatation, $>$ tubular necrosis, infiltration of mononuclear cells.

We thought that flavonoid fraction isolated from Artemisia campestris L. extract, harvested in Tunisia had probably similar bioactive compounds found by Hurabielle et al. (1982) and Rauter et al. (1989).

The antioxidant scavenging capacity of compounds has been attributed to various mechanisms such as prevention of chain inhibition, chelating metals, reductive capacity and radical scavenging (Yildirim et al. 2001). In the present study, the leaf extracts of Artemisia c. were tested for in vitro antioxidant activity using DPPH and reducing power.

DPPH assay is widely used as a model system in the assessment of the scavenging activities of several natural compounds. The current study revealed that the leaf extract of Artemisia c. exhibited high antiradical activity against $\mathrm{DPPH}^{\circ}$. The reductive capacity of the extract was enhanced when the concentration of samples increased. Besides, the antioxidant activity in the extract was found to be lower than that of ascorbic acid, used as standard reference. These results are in line with those obtained by Orčić et al. (2011) who reported the ability of Hypericum perforatum, a medicinal plant, to scavengeDPPH${ }^{\circ}$. The scavenging property of Artemisia $c$ might be due to hydroxyl groups present in the phenolic compounds' chemical structure that could provide the necessary component as a radical scavenger.

Reducing power, another indicator of antioxidant activity, was also studied. In fact, the current study showed that Artemisia c. leaf extract exhibited reducing power measured on the basis of $\mathrm{Fe}(\mathrm{III})$ to $\mathrm{Fe}(\mathrm{II})$ redox reaction. The increased absorbance of Artemisia c. leaf extracts indicated an enhanced reducing power. Our results are in accordance with other reports of Patra et al. (2011) who demonstrated that leaf extract of Suaeda maritime, a medicinal plant, had a strong reducing power. The Artemisia $c$. leaf extract reducing power indicated that bioactive compounds, especially flavonoids which were more presented than the total phenolic compounds and condensed tannins as reported previously by us (Sefi et al. 2010), acted as the secondary or preventive antioxidant in lipid peroxidation (LPO).

Medicinal plants react against oxidative damages to DNA molecules, proteins and membranes lipids induced by xenobiotics. In fact, LPO has been implicated in the pathogenesis of various kidney injuries (Soudani et al. 2010; Ben Amara et al. 2011; Troudi et al. 2011). The most widely used marker of LPO is MDA often assayed with the TBARS assay. In the cur- 

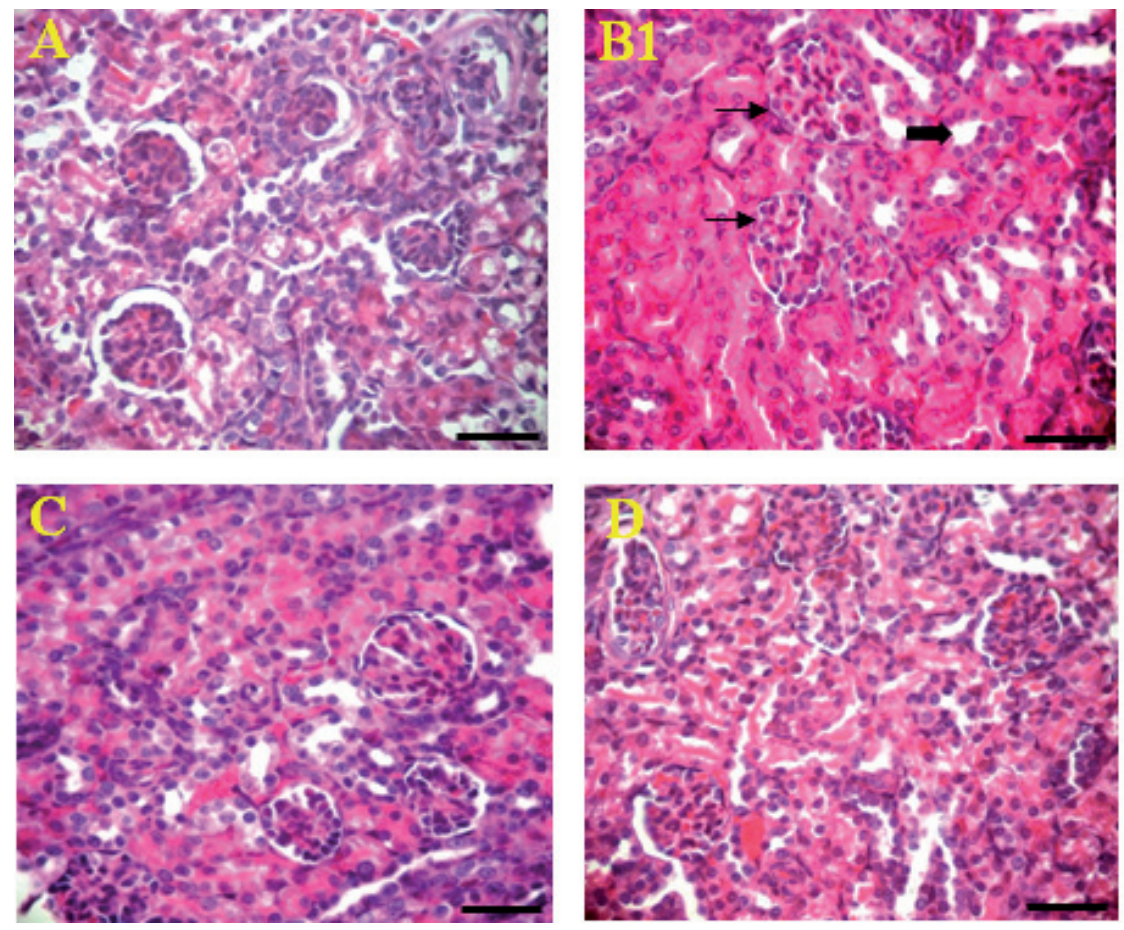

lin-eosin stain; Scale bar, $50 \mu \mathrm{m}$. Arrows indicate: $\longrightarrow$ glomeruli showing narrow Bowman's space, $\rightarrow$ tubular dilatation $\rightarrow$ granuloma inflammatory disorders.

rent study, fenthion caused an increase in the renal content of MDA in mothers and their pups. Our results are in line with previous studies using other pesticides like anilofos (Hazarika and Sarkar 2001) and diazinon (Altuntas et al. 2004; Gokalp et al. 2005). Based on the available information on metabolism in animals (Kitamura et al. 2003; Leoni et al. 2008), fenthion can undergo two major metabolic pathways: i) a sulfoxidation to fenthion-sulfoxide catalyzed by cytochrome $\mathrm{P}_{450}$ isoforms (CYPs) and/or flavin monooxygenases (FMOs), and ii) a CYPmediated oxidative desulfuration to form fenthion-oxon. It is possible that fenthion mediated free radical generation through the action of its metabolites, like fenthion-sulfoxide and fenthion-oxon, which have been hypothesized to be involved in LPO in tissues (Bagchi et al. 1995; Altuntaş and Delübaş 2002). In addition, the increase in LPO potential was associated with histological changes including the damaged renal tubules like necrotic epithelial cells with marked tubular dilatation and a narrowed Bowman's space and leucocytes infiltration around glomeruli and between tubules in the kidney of dams. In pups, a narrowed Bowman's space, a slight tubular dilatation and granuloma inflammatory disorders were shown. Our findings were in line with similar data reported in adult rats exposed to fenthion (Sefi et al. 2011) and to other pesticides (Sulak et al. 2005; Kalender et al. 2007; Fetoui et al. 2010; Troudi et al. 2011). The results of the current investigation revealed that the dietary supplementation of Artemisia c. leaf powder to fenthion-treated rats counteracted the renal dysfunction and morphological abnormalities. In fact, treatment with Artemisia c. leaf powder decreased renal content of MDA and moderately ameliorated kidney tissues. This normalization might be accomplished by the antioxidant and free radical quenching nature of the flavonoid rich fraction of Artemisia c., which protected the cells from fenthion -mediated damage.

To alleviate the effects of oxidative stress, the cells have several ways either by repairing the damage or by reducing the occurrence of oxidative damage by means of enzymatic and non-enzymatic antioxidants such as vitamins $\mathrm{E}$ and $\mathrm{C}$ (John et al. 2001). These antioxidants have also been shown to scavenge free radicals and reactive oxygen species (Mansour and Mossa 2009); for instance SOD catalyzes the conversion of superoxide radical to hydrogen peroxide, while CAT or GPx converts hydrogen peroxide to water. In our investigation, the significant increase in SOD, CAT and GPx renal activities in fenthion-treated rats could be a part of compensatory mechanism against oxidative stress and/or it might be the result of the nature of the tissue used, the experimental period and the dose of stressor. In fact, the subchronic exposure of rats to OPs (over a short period) results in an increased antioxidant capacity. This means that the body is able to defend itself by antioxidant overproduction (Handy et al. 2002; Akhgari et al. 2003). Our findings corroborated previous reports which found that several OPs caused an increase in the activities 
of antioxidant enzymes in some organs like liver, heart and pancreas (Akturk et al. 2006; Kamath et al. 2008; LukaszewiczHussain et al. 2008). Moreover, non-enzymatic antioxidants like reduced glutathione (GSH) and vitamins could prevent the uncontrolled formation of free radicals or inhibit their reaction with biological sites. In fact, GSH, which constitutes one of the physiologically important mechanisms to curtail the progression of tissue damage, is generally affected under oxidative stress conditions (Jollow et al. 1974). In our study, renal GSH levels remained unchanged in rats following fenthion treatment; this could be explained by an adaptative response to oxidative stress. Similar results have been reported in adult rats treated with dimethoate, another OP (Yukti et al. 2005). Treatment with Artemisia c. leaf powder improved antioxidant enzyme activities (SOD, CAT, GPx) in fenthion-treated dams and their pups, indicating a possible role of the polyphenols present in Artemisia c. extract in free radical inactivation and in the antioxidant defense.

24-h urine volumes are usually studied as indices of the functional integrity of renal proximal tubules, while proper glomerular function is assessed by examining the plasma creatinine or blood urea nitrogen (BUN) level (Friberg et al. 1986). In the present study, we found that 24 -h urine volumes significantly decreased in the fenthion -treated mothers and their pups, indicating severe renal failure. Our finding was apparently in agreement with that of Adachi et al. (2007) who reported a decrease in the urine volume of rats submitted to cadmium and fluoride. The decline in urine output found by us might be due to the action of fenthion, which could apparently have an antidiuretic effect. The impairment in the functional integrity of renal proximal tubules was accompanied by a significant increase in plasma creatinine and BUN in mothers and their pups treated with fenthion. Our results corroborated those of Fetoui et al. (2010) using lambda-cyhalothrin, a synthetic pyrethroid pesticide, in adult rats. Furthermore, the damage in glomerular filtration rate was objectified by a reduced creatinine clearance and a decline of 24 -h urinary excretion of creatinine and urea in fenthion-treated rats. These findings were in accordance with previous studies investigating dimethoate effects on the kidney of adult rats and their progeny (Mahjoubi-Samet et al. 2008). The kidney damage caused by fenthion exposure was shown to be alleviated after Artemisia $c$. leaf powder treatment. In fact, we have found a remarkable decrease in plasma creatinine and urea levels and an increase of 24-h urine volume and creatinine clearance. These results indicated that Artemisia $c$. leaf powder offered protection against fenthion nephrotoxicity and suggested that its protective effect was based on radical scavenging and on antioxidant activities. In line with this, we have recently confirmed the antioxidant activity of the Artemisia c., as monitored by the inhibition of lipid peroxidation and protein oxidation and also by the aptitude to scavenge superoxide and hydroxyl radicals in the pancreas of alloxan-induced diabetic rats (Sefi et al. 2010).
In view of the above findings, it was suggested that the phytochemical constituents of Artemisia c. could contribute by its antioxidant activity to nephroprotection.

\section{Conclusion}

In our study, we have shown for the first time that Artemisia c. treatment has a potent protective effect against oxidative stress and kidney damage induced by fenthion in both dams and suckling pups, as revealed by a remarkable improvement of biochemical and histological abnormalities. We conclude that Artemisia c. has protective effects through its antioxidant capacity on kidney injuries induced by fenthion.

Acknowledgements. This work was supported by the DGRST grants (Appui à la Recherche Universitaire de base, ARUB 99/ UR/08-73), Tunisia. The authors are indebted to Miss Dalenda Kchaou for her assistance in histological techniques. We also wish our thanks to Mr Hafedh Bejaoui, teacher of English at Sfax faculty of Science, who has proof read and edited this paper.

The authors declared no conflicts of interest.

\section{References}

Adachi K., Dote T., Dote E., Mitsui G., Kono K. (2007): Strong acute toxicity, severe hepatic damage, renal injury and abnormal serum electrolytes after intravenous administration of cadmium fluoride in rats. J. Occup. Health 49, 235-241

http://dx.doi.org/10.1539/joh.49.235

Aebi H. (1984): Catalase in vitro. Methods Enzymol. 105, $121-126$ http://dx.doi.org/10.1016/S0076-6879(84)05016-3

Akhgari M., Abdollahi M., Kebryaeezadeh A., Hosseini R., Sabzevari O. (2003): Biochemical evidence for free radicalinduced lipid peroxidation as a mechanism for sub chronic toxicity of malathion in blood and liver of rats. Hum. Exp. Toxicol 22, 205-211 http://dx.doi.org/10.1191/0960327103ht346oa

Akrout A. (2005) : Contribution à l'étude chimique et activités biologiques d'Artemisia campestris L, Thèse en Chimie, Faculté des Sciences de Sfax, Tunisia

Akrout A., Gonzalez L. A., El Jani H. (2011): Antioxidant and antitumor activities of Artemisia campestris and Thymelaea hirsuta from southern Tunisia. Food. Chem. Toxicol. 49, 342-347 http://dx.doi.org/10.1016/j.fct.2010.11.003

Akturk O., Demirin H., Sutcu R., Yilmaz N., Koylu H. I. (2006): The effects of diazinon on lipid peroxidation and antioxidant enzymes in rat heart and ameliorating role of vitamin $\mathrm{E}$ and vitamin C. Cell. Biol. Toxicol. 22, 455-461 http://dx.doi.org/10.1007/s10565-006-0138-5

Altuntas I., Kilinc I., Orhan H., Demirel R., Koylu H., Delibas N. (2004): The effects of diazinon on lipid peroxidation and antioxidant enzymes in erythrocytes in vitro. Hum. Exp. Toxicol. 23, 9-13 http://dx.doi.org/10.1191/0960327104ht408oa 
Altuntaş Ü., Delübaş N. (2002): The effects of fenthion on lipid peroxidation and some liver enzymes: the possible protective role of vitamins E and C. Turk. J. Med. Sci. 32, 293-297

Aniya Y., Shimabukuro M., Shimoji M., Kohatsu M., Gyamfi M. A., Miyagi C., Kunii D., Takayama F., Egashira T. (2000): Antioxidant and hepatoprotective actions of the medicinal herb Artemisia campestris from the Okinawa Islands. Biol. Pharm. Bull. 23, 309-312 http://dx.doi.org/10.1248/bpb.23.309

Bagchi D., Bagchi M., Hassoun E. A., Stohs S. J. (1995): In vitro and in vivo generation of reactive oxygen species, DNA damage and lactate dehydrogenase leakage by selected pesticides. Toxicology 104, 129-140 http://dx.doi.org/10.1016/0300-483X(95)03156-A

Beauchamp C., Fridovich I. (1971): Superoxide dismutase: improved assays and an assay applicable to acrylamide gel. Anal. Biochem. 44, 276-287 http://dx.doi.org/10.1016/0003-2697(71)90370-8

Ben Amara I., Troudi A., Garoui El M., Hakim A., Boudawara T., Zeghal N. (2011): Protective effects of selenium on methimazole nephrotoxicity in adult rats and their offspring. Exp. Toxicol. Pathol. 63, 553-561 http://dx.doi.org/10.1016/j.etp.2010.04.007

Bouvier G., Blanchard O., Momas I., Seta N. (2006): Pesticide exposure of non-occupationally exposed subjects compared to some occupational exposure: a French pilot study. Sci. Total. Environ. 366, 74-91 http://dx.doi.org/10.1016/j.scitotenv.2005.08.016

Charrel M. (1991): Urée et créatinine. In: Semiologie Biochimique. pp. 124-128, Ellipses Publisher, Paris

Council of European Communities (1986): Council Instructions about the Protection of Living Animals Used in scientific Investigations Official Journal of the European Communities. (JO 86/609/CEE), L358, pp. 1-18

Cuenod A., Pottier-Alapetite G., Labre A. (1954): Flore Analytique et Synoptique de la Tunisie: Cryptogames Vasculaires Gymnospermes et monocotyledones, Office de l'experimentation et de la vulgarisation agricoles de Tunisie. pp. 39-287, Tunis

Djeridane A., Yousfi M., Nadjemi B., Boutassouna D., Stocker P., Vidal N. (2006): Antioxidant activity of some Algerian medicinal plants extracts containing phenolic compounds. Food. Chem. 97, 654-660 http://dx.doi.org/10.1016/j.foodchem.2005.04.028

Draper H. H., Hadley M. (1990): Malondialdehyde determination as index of lipid peroxidation. Methods. Enzymol. 86, 421-431 http://dx.doi.org/10.1016/0076-6879(90)86135-I

Eddleston M., Phillips M. R. (2004): Self-poisoning with pesticides. Br. Med. J. 328, 42-44 http://dx.doi.org/10.1136/bmj.328.7430.42

Eddleston M., Eyer P., Worek F., Mohamed F., Senarathna L., Von Meyer L., Juszczak E., Hittarage A., Azhar S., Dissanayake W., Sheriff M. H., Szinicz L., Dawson A. H., Buckley N. A. (2005): Differences between organophosphorus insecticides in human self-poisoning: a prospective cohort study. Lancet 366, 1452-1459 http://dx.doi.org/10.1016/S0140-6736(05)67598-8

Eddleston M., Buckley N. A., Eyer P., Dawson A. H. (2007): Management of acute organophosphorus pesticide poisoning. Lancet 371, 597-607
http://dx.doi.org/10.1016/S0140-6736(07)61202-1

Edwards J. W., Lee S. G., Heath L. M., Pisaniello D. L. (2008): Worker exposure and a risk assessment of malathion and fenthion used in the control of Mediterranean fruit fly in south Australia. Environ. Res. 103, 38-45 http://dx.doi.org/10.1016/j.envres.2006.06.001

Ellman G. L. (1959): Tissue sulfhydryl groups. Arch. Biochem. Biophys. 82, 70-77 http://dx.doi.org/10.1016/0003-9861(59)90090-6

Emteres R., Abdelghani A. A., Anderson A. C. (1986): Subacute toxicity of Fenthion to New Zealand white rabbits (Orcyctalagus cunticulus). Environ. Tech. Lett. 7, 27-30 http://dx.doi.org/10.1080/09593338609384388

Fetoui H., Makni M., Garoui E. M., Zeghal N. (2010): Toxic effects of lambda-cyhalothrin, a synthetic pyrethroid pesticide, on the rat kidney: Involvement of oxidative stress and protective role of ascorbic acid. Exp. Toxicol. Pathol. 62, 593-599 http://dx.doi.org/10.1016/j.etp.2009.08.004

Fishbeck K. L., Rasmussen K. M. (1987): Effect of repeated cycles on maternal nutritional status lactational performance and litter growth in ad libitum fed and chronically food restricted rats. J. Nutr. 117, 1967-1975

Flohe L., Gunzler W. A. (1984): Assays of glutathione peroxidise. Methods. Enzymol. 105, 114-121 http://dx.doi.org/10.1016/S0076-6879(84)05015-1

Friberg L., Kjellstrőm T., Nordberg G. F. (1986): Cadmium. In: Handbook on the Toxicology of Metals (2nd ed.). (Eds. L. Friberg, G. F. Nordberg, V. B. Vouk), pp. 130-184, Elsevier, Amsterdam

Gabe M. (1968): Histological Technics. Masson Publisher, Paris

Gokalp O., Buyukvanli B., Cicek E., Ozer K., Koyu A., Altuntas I., Koylu H. (2005): The effects of diazinon on pancreatic damage and ameliorating role of vitamin $\mathrm{E}$ and vitamin C. Pestic. Biochem. Phys. 81, 123-128 http://dx.doi.org/10.1016/j.pestbp.2004.11.001

Handy R. D., Abd-El Samei H. A., Bayomy M. F., Mahran A. M., Abdeen A. M., El-Elaimy E. A. (2002): Chronic diazinon exposure: pathologies of spleen, thymus, blood cells, and lymph nodes are modulated by dietary protein or lipid in the mouse. Toxicology 172, 13-34 http://dx.doi.org/10.1016/S0300-483X(01)00575-3

Hazarika A., Sarkar S. N. (2001): Effect of isoproturon pretreatment on the biochemical toxicodynamics of anilofos in male rats. Toxicology 165, 87-95 http://dx.doi.org/10.1016/S0300-483X(01)00411-5

Hurabielle M., Eberle J., Paris M. (1982): Flavonoids of Artemisia campestris ssp. glutinosa. Planta. Med. 46, 124-125 http://dx.doi.org/10.1055/s-2007-970035

John S., Kale M., Rathore N., Bhatnagar D. (2001): Protective effect of vitamin $\mathrm{E}$ in dimethoate and malathion induced oxidative stress in rat erythrocytes. J. Nutr. Biochem. 12, 500-504 http://dx.doi.org/10.1016/S0955-2863(01)00160-7

Jollow D. J., Mitchell J. R., Zamppaglione Z., Gillette J. R. (1974): Bromobenzene induced liver necrosis. Protective role of glutathione and evidence for 3,4-bromobenzene oxide as the hepatotoxic metabolites. Pharmacology 11, 151-157 http://dx.doi.org/10.1159/000136485

Kalender S., Kalender Y., Durak D., Ogutcu A., Uzunhisarcikli M., Cevrimli B. S., Yildirim M. (2007): Methyl parathion induced 
nephrotoxicity in male rats and protective role of vitamins $\mathrm{C}$ and E. Pestic. Biochem. Physiol. 88, 213-218

http://dx.doi.org/10.1016/j.pestbp.2006.11.007

Kamath V., Joshi A. K. R., Rajini P. S. (2008): Dimethoate induced biochemical perturbations in rat pancreas and its attenuation by cashew nut skin extract. Pest. Biochem. Physiol. 90, 58-66 http://dx.doi.org/10.1016/j.pestbp.2007.07.007

Kerem M., Bedirli N., Gürbüz N., Ekinci Ö., Bedirli A., Akkaya T., Sakrak Ö., Paşaoğlu H. (2007): Effects of acute fenthion toxicity on liver and kidney function and histology in rats. Turk. J. Med. Sci. 37, 281-288

Kitamura S., Suzuki T., Kadota T., Yoshida M., Ohashi K., Ohta S. (2003): In vitro metabolism of fenthion and fenthion sulfoxide by liver preparations of sea bream, goldfish, and rats. Drug. Metab. Dispos. 31, 179-186 http://dx.doi.org/10.1124/dmd.31.2.179

Le Floch E. (1983): Contribution à une Etude Ethnobotanique de la Flore Tunisienne. (Ed. I. O. R.), pp. 216-217, Tunis, Tunisia

Leoni C., Buratti F. M., Testai E. (2008): The participation of human hepatic $\mathrm{P} 450$ isoforms, flavin-containing monooxygenases and aldehyde oxidase in the biotransformation of the insecticide fenthion. Toxicol. Appl. Pharmacol. 233, 343-352 http://dx.doi.org/10.1016/j.taap.2008.09.004

Liyana-Pathiranan C. M., Shahidi F. (2005): Antioxidant activity of commercial soft and hard wheat (Triticum aestivum L.) as affected by gastric $\mathrm{pH}$ conditions. J. Agri. Food. Chem. 53, 2433-2440 http://dx.doi.org/10.1021/jf049320i

Lowry O. H., Rosenbrough N. J., Farr A. L., Randall R. J. (1951): Protein measurement with the Folin phenol reagent. J. Biol. Chem. 193, 265-275

Lukaszewicz-Hussain A., Moniuszko-Jakoniuk J., Roszczenko A. (2008): Effects of subchronic chlorfenvinphos administration on liver antioxidative parameters and lipid peroxidation marker in experimental rats. Toxicol. Environ. Chem. 90, 7-13 http://dx.doi.org/10.1080/02772240701234506

Mahjoubi-Samet A., Fetoui H., Zeghal N. (2008): Nephrotoxicity induced by dimethoate in adult rats and their suckling pups. Pestic. Biochem. Physiol. 91, 96-103 http://dx.doi.org/10.1016/j.pestbp.2008.01.009

Mansour S. A., Mossa A. H. (2009): Lipid peroxidation and oxidative stress in rat erythrocytes induced by chlorpyrifos and the protective effect of zinc. Pestic. Biochem. Phys. 93, 34-39 http://dx.doi.org/10.1016/j.pestbp.2008.09.004

Memmi A., Sansa G., Rjeibi I., El Ayeb M., Srairi-Abid N., Bellasfer Z., Fekhih A. (2007): Use of medicinal plants against scorpionic and ophidian venoms. Arch. Inst. Pasteur. Tunis 84, 49-55

Orčić D. Z., Mimica-Dukić N. M., Francišković M. M., Petrović S. S., Jovin E. Đ. (2011): Antioxidant activity relationship of phenolic compounds in Hypericum perforatum L. Chem. Cent. J. 5, 34 http://dx.doi.org/10.1186/1752-153X-5-34

Oyaizu M. (1986): Studies on products of browning reaction - antioxidative activities of products of browning reaction prepared from glucosamine. Japanese J. Nutr. 44, 307-315 http://dx.doi.org/10.5264/eiyogakuzashi.44.307

Patra J. K., Dhal N. K., Thatoi H. N. (2011): In vitro bioactivity and phytochemical screening of Suaeda maritima (Dumort): A mangrove associate from Bhitarkanika, India. Asian. Pac. J. Trop. Med. 4, 727-734
http://dx.doi.org/10.1016/S1995-7645(11)60182-X

Rauter A. P., Branco I., Tostao Z., Pais M. S., Gonzalez A. G., Bermejo B. (1989): Flavonoids from Artemisia campestris ssp maritima. Phytochemistry 28, 2173-2175 http://dx.doi.org/10.1016/S0031-9422(00)97938-X

Saoudi M., Allagui M. S., Abdelmouleh A., Jamoussi K., El Feki A. (2010): Protective effects puffer of aqueous extract of Artemisia campestris puffer fish Lagocephalus lagocephalus extract-induced oxidative damage in rats. Exp. Toxicol. Pathol. 62, 601-605 http://dx.doi.org/10.1016/j.etp.2009.08.003

Sefi M., Fetoui H., Makni M.,Zeghal N. (2010): Mitigating effects of antioxidant properties of Artemisia campestris leaf extract on hyperlipidemia, advanced glycation end products and oxidative stress in alloxan-induced diabetic rats. Food Chem. Toxicol. 48, 1986-1993 http://dx.doi.org/10.1016/j.fct.2010.05.005

Sefi M., Bouaziz H., Soudani N., Boudawara T., Zeghal N. (2011): Fenthion-induced oxidative stress in the liver of adult rats and their progeny: Alleviation by Artemisia campestris. Pestic. Biochem. Physiol. 101, 71-79 http://dx.doi.org/10.1016/j.pestbp.2011.08.002

Soudani N., Sefi M., Ben Amara I., Boudawara T., Zeghal N. (2010): Protective effects of Selenium (Se) on Chromium (VI) induced nephrotoxicity in adult rats. Ecotoxicol. Environ. Saf 73, 671-678 http://dx.doi.org/10.1016/j.ecoenv.2009.10.002

Soudani N., Sefi M., Bouaziz H., Chtourou Y., Boudawara T., Zeghal N. (2011): Nephrotoxicity induced by chromium (VI) in adult rats and their progeny. Hum. Exp. Toxicol. 30, 1233-1245 http://dx.doi.org/10.1177/0960327110387454

Sulak O., Altuntas I., Karahan N., Yildirim B., Akturk O., Yilmaz H. R., Delibas N. (2005): Nephrotoxicity in rats induced by organophosphate insecticide methidathion and ameliorating effects of vitamins E and C. Pestic. Biochem. Physiol. 83, 21-28 http://dx.doi.org/10.1016/j.pestbp.2005.03.008

Troudi A., Soudani N., Mahjoubi Samet A., Ben Amara I., Zeghal N. (2011): 2,4-Dichlorophenoxyacetic acid effects on nephrotoxicity in rats during late pregnancy and early postnatal periods. Ecotoxicol. Environ. Saf 74, 2311-2323 http://dx.doi.org/10.1016/j.ecoenv.2011.07.032

Uz E., Karatas O. F., Mete E., Bayrak R., Bayrak O., Atmaca A. F., Atis O., Yildirim M. E., Akcay A. (2009): The effect of dietary ginger (Zingiber officinals Rosc) on renal ischemia/reperfusion injury in rat kidneys. Ren. Fail. 31, 251-260 http://dx.doi.org/10.1080/08860220902779921

Yen G-C., Chen H-Y. (1995): Antioxidant activity of various tea extracts in relation to their antimutagenicity. J. Agric. Food. Chem. 43, 27-37

http://dx.doi.org/10.1021/jf00049a007

Yildirim A., Mavi A., Kara A. A. (2001): Determination of antioxidant and antimicrobial activities Rumaxs crispus L. extracts. J. Agric. Food. Chem. 49, 4083-4089 http://dx.doi.org/10.1021/jf0103572

Yukti S., Somia B., Irshad M., Datta S., Gupta Dogra T. D. (2005): Effects of acute dimethoate administration on antioxidant status of liver and brain of experimental rats. Toxicology 206, 49-57 http://dx.doi.org/10.1016/j.tox.2004.06.062

Received: January 2, 2013

Final version accepted: April 24, 2013 